\title{
P-TECHNIQUE
}

\section{A NEW STATISTICAL DEVICE FOR ANALYSING FUNCTIONAL UNITIES IN THE INTACT ORGANISM}

\author{
BY \\ RAYMOND B. CATTELL and HENRIETTA F. V. M. WILLIAMS \\ Psychology Department, University of Illinois
}

(1) Place of P-technique in Scientific Method

The methods of science lie in a continuum, at one end of which is complete experimental control, in which all significant conditions beyond those of the independent variable are held constant while changes in a dependent variable are related to controlled changes in the independent variable. This we may call the classical experimental method of the physical sciences. At the other end of the continuum we have the experimental design, in which practically nothing is controlled or controllable, but in which observations are made on a number of variables representing natural processes which occur in the organism in situ.

Biological sciences have, in the main, made great efforts to imitate the physical sciences by using, wherever possible, the classical, controlled experiment. However, this has naturally been done at the cost of neglecting a number of important problems involving the total organism in its natural setting, and and often by resort to very awkward experimental arrangements. Physiology, as well as psychology and the social sciences, is faced with the problem of finding interrelationships among variables in a complex situation. In physiology, this complex situation is the organism or even one organ, with its many variables influencing each other in some way. The controlled classical experiment ignores these complex relationships, and, by its very nature, can clarify certain relationships only under very specific conditions.

Until recently, it was not appreciated that the same problems that were being tackled by such contortions of the classical experimental approach, and often at the cost of working upon "physiological preparations" not strictly comparable with the intact organism, are now capable of being tackled by improved statistical methods aimed at allowing for the influences which could not be controlled, and permitting relations to be analysed while the organism is performing in its natural totality and in its natural environment. Outstanding among these modern statistical methods is the method of factor analysis (Cattell, 1952, Thurstone, 1949). It is the purpose of the present paper to attack the problem of measuring the inter-relationships of several variables in the organism in situ by the technique of factor analysis, and to do so by means of a fairly substantial example in experimental research.

Although it is possible to use factor analysis in connection with some degree of experimental control, it is typically used with no control whatever. That is to say, an organism, or even an organ, is measured with respect to, say, twenty or thirty variables, which are believed to be interrelated in some way and which are allowed to vary naturally, i.e. under the impact of natural demands. Correlations are then worked out among these measurements. By the method of factor analysis applied to the correlations, it is possible to show, usually, that the functional interconnections are due to a relatively small number of factors, maybe five to ten in the case of thirty or so variables. These factors are underlying influences, or sources of variation, which are responsible for the observed correlations. In the physiological realm, such an underlying influence might be an endocrine substance, a pattern of autonomic innervation, and so on. The factor analytic method is especially potent in bringing out patterns which could only be found by a lengthy series of related researches if variables were taken only two at a time, as is typical of the classical experiment. It also has the special value of being able to deal with the total organism and of isolating, by statistics rather than by experimental dissection, the functional unities which might vanish under physical experimental control.

Factor analysis can be applied in a number of distinctive experimental designs or techniques, of which there are basically three, known as R-, P-, and T-techniques (Cattell, 1952). Only the first two are of importance for physiology. In R-technique one takes a population of say a hundred individuals and measures each on the same thirty variables 
involved. The correlations then obtained amongthe variables depend upon individual differences. That is to say, if individual $\mathrm{X}$ is higher in one manifestation of thyroid activity, we should expect him also to be higher in the other measures of thyroid activity, so that correlation of these various activities, along with activities which have nothing to do with the thyroid, would allow the former to stand out from the latter as a pattern of positively correlated variables. This is the commonest form of factor analysis in psychology. More recently, however, a form of factor analysis has been developed, called P-technique (Cattell and others, 1947; Cattell and Luborsky, 1950; Cattell, 1952), which will have more appeal to the physiologist because it deals with the single organism. In this technique, a single person or organism is measured on a number of variables over a hundred days or a hundred occasions separated in time or by experimental conditions. Thus, a correlatable series is obtained for each of the variables involved. For example, one might measure the adrenaline level and glucose concentration in the blood on each of the hundred days, in regard to which a positive correlation would indicate some degree of functional connection.

Some of the goals of this method have already been anticipated by experimental and clinical psychologists in the trend toward measuring many variables simultaneously on one animal instead of a few on many animals. But this move in the direction of "holistic" functional understanding has so far not availed itself of the statistical method-the factor analysis of the single organism - which can objectively discover the functional unities.

Physiological research (Best and Taylor, 1945) has also used repeated measurements of a variable (notably in the work of the haematologists) and has correlated such series, as in the basis of P-technique, but here also it has stopped short of the integration reached by the latter, notable in that it has interfered with the natural interactions by bringing its special stimuli (experimental influences which are grosser than the others), and that it has attempted to interpret the correlations one by one instead of by the global factor analytic method.

It is principally in this latter respect that Ptechnique transcends anything that can be done with correlations alone. As stated earlier, the question whether one allows the physiological changes to occur spontaneously from occasion to occasion, under the impact of natural adaptive demands, or whether one deliberately introduces stimulus conditions, is a relatively minor matter of design.

Medicine seems to have proceeded on the assumption that, though there are individual differences in the intensity of the particular processes, the same general physiological processes will occur in everyone. This is based on the empirical fact that the same patterns of reaction are observed in different people. P-technique simply extends this approach by making the analysis of what goes on in a particular individual more detailed and exact. However, when it is to be thorough, the generalization as to what will happen in people in general still requires the accumulation of quite a number of P-technique studies. It is for that reason that we have not proceeded very far with basic generalizations from the following data, since we await other P-technique studies with the same variables. The only existing $\vec{?}$ studies in P-technique are those of Cattell and others (1947), Cattell and Luborsky (1950), and Williams (1949), so far using largely psychological variables. The reader may be interested to study these from a $\stackrel{?}{?}$ methodological point of view or to compare them $v$ with the present study in relation to the few physiological variables which were included in them, but $\vec{\nexists}$ the present study is the only one in existence of a primarily physiological nature. Even in this study we have included some psychological variables as a $\vec{c}$ matter of interest, particularly to show the value of $\stackrel{一}{\gtrless}$ the method in psychosomatic studies.

\section{(2) Design of the Experiment and Definition VARIABLES}

Although it is true that any experimental statistic design permits one to look for a law in the relation between certain variables, without entering the experiment with too definite a hypothesis as to what form the law must take, factor analysis is unique in demanding no prior hypothesis and in being automatically productive of a hypothesis. One may start with a highly specific hypothesis about the forms and relations of the factors, but this is not necessary. For a pattern of factor loadings - a cluster of variables-suggests immediately something about the nature of a certain influence behind them. This creates the hypothesis by which one enters the next experiment into which some new variable can now be inserted and which may be designed more explicitly to measure the hypothesized influence. But in entering the initial factor analytic study one need not have any more definite a hypothesis than is necessary to choose a set of variables, the relations among which are likely to be of interest, in this case to human physiology.

Thus, in the experiment now to be described, we chose a set of variables primarily on the grounds that they were $O$

(a) very varied and representative of many aspects of the organism's functioning,

(b) known from physiological research to be measurable with experimental accuracy,

(c) already indicated as having some relevance to psychological states,

(d) known to vary appreciably from day to day,

(e) susceptible to repeated measurement without practice effects or other objections to day-to-day testing. 
Furthermore, although this is in one sense a pioneer factorization of the whole psychosomatic field, yet there are partial factorizations, e.g. Wenger on the autonomic system (Cattell, 1950), Cureton (1947) on the cardiovascular system, and Cattell and Luborsky (1950) on personality factors in the psychosomatic area, which gave us prior indications of what variables might form the centres of functional clusters. The $36^{*}$ resulting objective and performance variables, and the 31 psychological behaviour rating variables, were thus in fact carefully chosen to be representative, important, and indicated by exploratory factor analyses.

\section{Tests}

The tests were given in the order in which they are presented here (and in Table I) to a normally healthy 23-year-old male graduate student at the university. They were given daily at different hours, to explore fatigue effects, for 110 consecutive days. $\dagger$

\section{TABLE I}

RANGE OF SCORES

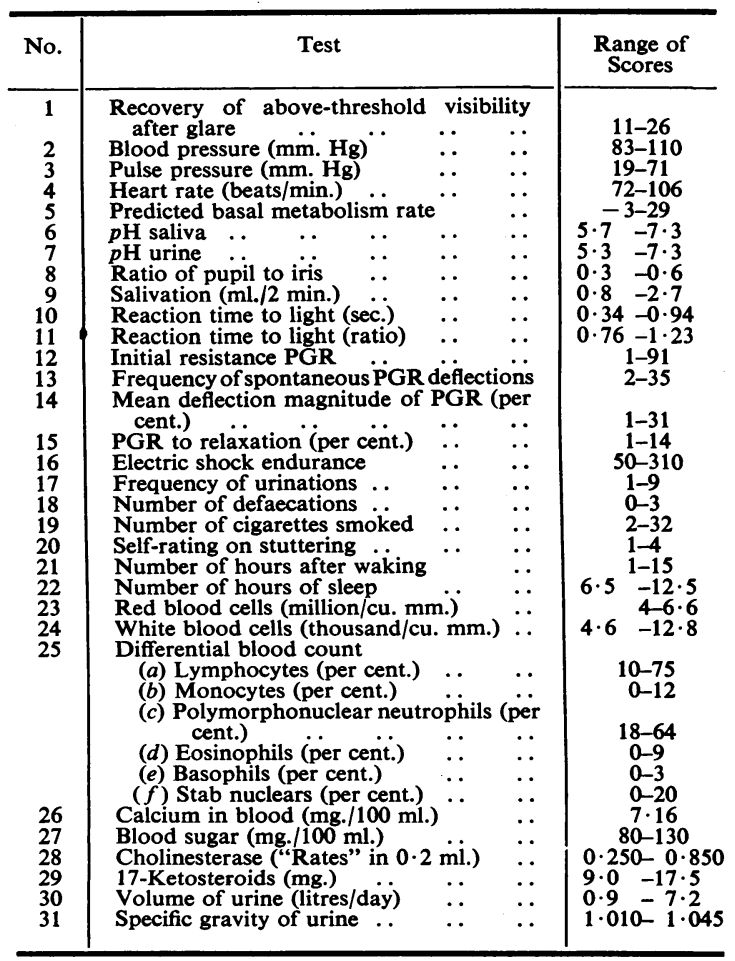

*Item 25 in the 31 variables listed below under TeSTS, and in Table I, has six sub-sections making 36 measures in all.

t It was impossible to obtain measures on all variables, such as glucose and calcium content of the blood, on this one individual for each of the days the tests were run. The number of measurements made on each variable follows immediately after the title of each variable with the notation $N=$.
(1) ReCOVERY OF ABOVE-Threshold Visibility AFTER GLARE $(N=107)^{*}$.- The subject looked into a box, in which a photoflood light was shining, for $30 \mathrm{sec}$. At the end of that period, the photoflood light was turned off and a 5-watt bulb turned on. Simultaneously a screen was dropped which revealed a letter of the alphabet. At the time the 5-watt bulb was turned on and the letter of the alphabet was revealed, a reaction-time clock automatically started and was stopped by the subject pressing a key as soon as he could identify the letter. The score was the number of seconds (measured to the nearest hundredth of a second) before the subject could identify the letter of the alphabet.

(2) Blood Pressure $(N=48)$.- The systolic and diastolic blood pressures were taken both by the cardiometer and by means of the stethoscope while the subject was sitting down. The score was the average of the obtained four figures.

(3) Pulse Pressure $(N=48)$.- The score used was the mean of the two pulse pressures found by using the cardiometer and the stethoscope.

(4) Heart Rate $(N=110)$.- The subject counted the pulse beat for one minute.

(5) Gale's Formula for Predicted Basal Metabolism RATE $(N=48)$. - Gale's formula, B.M.R. = Pulse Pressure + Pulse Rate -111 , was used in calculating the basic metabolic rate (10).

(6) $p \mathrm{H}$ of SAliva $(N=108)$.- The $p \mathrm{H}$ of the saliva was measured immediately using a Beckman $p \mathrm{H}$ meter.

(7) $p \mathrm{H}$ of URINe $(N=107)$.- The $p \mathrm{H}$ of fresh urine was measured using a Beckman $p \mathrm{H}$ meter.

(8) Ratio of Pupil to Iris $(N=104)$.-The subject, always keeping his eyes at a particular spot in the room, was placed in a position so that his right eye was exactly 18 in. from a fluorescent light. This distance was held constant by a wire extending from the base of the lamp, with a loop, where the subject was to place his eye. The blinds were always drawn and the overhead light and the fluorescent light were always on, so that the amount of light present was constant. A moving picture was taken of the eye one minute after the fluorescent light was snapped on. On each day, a picture of the date was also taken, so that after the film was developed, the first picture taken for each day was scored. The score was the ratio of the size of the pupil to the iris.

* Owing to some doubtful readings, etc., having to be rejected, the full series of 110 measurements was not obtained in all cases (and in some variables measures were taken only on alternate days). In these variables the correlation is calculated for a shorter series and in order that the standard error of the coefficient may be properly appreciated that the standard error of the coefficient may be properly appreciated
we give after each variable the $\mathrm{N}$ (population of occasions) on which it is based. 
(9) Salivation $(N=108)$. - The subject collected all the saliva that he could for a period of 2 min., and at the end of that period it was measured in a tube graduated in $0.2 \mathrm{ml}$.

(10-11) Reaction Time to Light $(N=110)$.-The subject looked into a dark box and was told to tap a key as soon as a photoflood light was flashed on. For the first ten times, he always was given a warning of "Ready" $2 \mathrm{sec}$. before the light was flashed on. For the last ten trials, however, he was given warnings of "Ready" which varied randomly from 1 to $3 \mathrm{sec}$. before the light was flashed on. Two scores were obtained from these data: one was the mean reaction time of the total twenty trials; the other was the mean of the first ten trials with regular 2 sec. warnings, divided by the mean of the ten trials with irregular warnings.

(12) PsychogalvanicSkin Response(Intial Resistance) $(N=107)$. - A conventional PGR apparatus was used, consisting of a Wheatstone bridge with the hand resistance in series with a recording variable resistance. The subject's right hand was placed on the arm of a chair on which was fastened a leather band. When the leather band was wrapped around the subject's wrist, a zinc electrode came in contact with it just below the palm of the hand. The other zinc electrode, covered with a sponge soaked in a 5 per cent. sodium chloride solution, was applied to the palm of the hand. The PGR initial resistance was taken one minute after the subject was connected to the apparatus. The score taken was the dial reading at that time (Cattell, 1929).

(13) Frequency of Spontaneous PGR Deflections $(N=107)$. - The subject was told to look. into a dark box for $3 \mathrm{~min}$. The number of deflections above 5 per cent. of the scale value during the $3 \mathrm{~min}$. interval was recorded as the score.

(14) Mean Magnitude of PGR Deflection $(N=84)$. While the subject remained connected to the PGR apparatus, the following tests were given:

(a) He was told to look into a lighted box, at the further end of which was a list consisting of eighteen new words each day. He was told to memorize them by reading the list as many times as possible. One minutes was allowed for this memorization.

(b) 15 sec. after the light was turned off in the box. there was a loud noise made by clashing cymbals together three times.

(c) During this entire procedure, he had a silver-plated electrode wrapped around his left wrist. In his left hand he was holding another electrode. $30 \mathrm{sec}$. after the loud noise was heard, he received a severe electric shock.

(d) 2 min. 15 sec. after the electric shock was given, the subject was given $90 \mathrm{sec}$. to recall the words previously memorized.

One PGR score was taken from the above data. This score was the average percentage change (loss) of resistance to the above situations.
(15) PGR Magnitude of Upward Drift in Relaxing $(N=96)$. - The subject was told to relax as much as possible. The score taken was the percentage change (rise) of the resistance.

(16) Endurance of Electric SHock $(N=110)$. - A $\frac{3}{8}$ low amperage electric current supplied at a constant $?$ intermittent rate was delivered to the subject through $\vec{F}$ two electrodes. The voltage was controlled by a rheostat. $\stackrel{\oplus}{+}$ The subject had both electrodes in the same hand. The voltage of the electric current was gradually increased from zero up to a point where the subject reported that he would endure it no longer. The score taken was the position on the dial at which the subject reported the mounting electric shock was becoming unbearable.

A record was made each day of the number of times the following items occurred after waking until the time of the day the tests were taken.

(17) NUMBer of Urinations $(N=110)$.

(18) Number of Defaecations $(N=110)$.

(19) Number of Cigarettes SMoked $(N=110)$.

(20) Stuttering (a trait of this subject).-A self-rating 윽 was made by the subject on the degree of stuttering during the day. The subject rated this on a scale varying $\subsetneq$ from one to four points. If he felt he had stuttered badly during the day, he rated himself as four; if he rated $\vec{\oplus}$ himself as one, he was free of any blocking of speech. on He had formerly been classified as a stutterer, but in the 2 years preceding this study was no longer so classifie. He reports, however that there are subjective "feeling of stuttering" when he is talking and in a state of tension:

(21) Number of Hours after Waking until Tests WERE GIVEN $(N=110)$.

(22) Length of Sleep on Previous Night $(N=110)$.

(23) Red Blood Cells $(N=92)$.-Two red blood cell counts were always made, and at no time during the entire 92 days did the two counts at one occasion vary more than 300,000 red blood cells per c.mm. The score used was the mean between the two determinations.

(24) White Blood Cells $(N=88)$. - Two determinations of white blood cells were made each day and at no time during the 88 determinations did the two counts differ more than 250 white blood cells per c.mm. The score used was the mean of the two determinations.

(25) Differential Blood Count $(N=73)$.- This was made using Wright's solution, and the following scores were taken in percentages:
(a) Lymphocytes
(b) Monocytes
(c) Polymorphonuclear Neutrophils
(d) Eosinophils
(e) Basophils
(f) Stab Nuclears 
(26) Calcium Content of Blood Serum $(N=30)$. This was determined by the Clark-Collip method.

(27) Glucose Content of Blood Serum $(N=30)$. - This was determined by the method of Folin and Wu.

(28) Cholinesterase $(N=15)$. - The procedure described by Alles and Hawes (1940) was followed, except that $50 \mathrm{mg}$. acetylcholine was used instead of $100 \mathrm{mg}$. in the substrate. The values obtained are the "Rates" defined by Alles and Hawes (1940) and originally established by Stedman, Stedman, and Easson (1932). The value used was the "rate" of cholinesterase found on $0.2 \mathrm{ml}$. blood serum.

(29) 17-Ketosteroims $(N=22)$.-A 24-hour sample of urine was collected each day and the 17-ketosteroids measured as described by Todd and Sanford (1939).

(30) Volume of Urine since Awakening IN MoRning $(N=36)$. - This was recorded just before the subject retired for the night.

(31) Specific Gravity of Urine $(N=36)$.

(32) Serial Number of Session $(N=110)$.

Psychological VARIAbles.-Each day of the 110-day interval, ratings were made on the subject's behaviour after the above objective tests were given.

The subject rated himself on a graphic scale running from 0 to 100 on the following eighteen questions:

(a) Do you feel relatively shy and self-conscious to-day, so that you have tended to keep in the background on social occasions?

(b) Have you felt to-day that your mind has tended to move slowly so that you keep to one track in conversation instead of jumping about?

(c) Have you felt to-day rather easily excited and rattled in difficult situations?

(d) Do you feel unduly sensitive so that your feelings are easily hurt by remarks?

(e) Have you felt depressed and miserable for no good reason or have you felt above average in spirits?

$(f)$ Have you felt unduly worried and tense to-day or not?

( $g$ ) Have you suffered to-day from periods of loneliness?

(h) Is this a day on which everything seems to have gone wrong or on which things go well?

(i) Have you been day-dreaming much to-day?

(j) Has your memory been good to-day or poor and uncontrolled?

(k) Have you felt to-day generally very self confident or lacking in confidence?

( $(l)$ When things have gone wrong to-day do you think it has been mainly your fault or the fault of others?

( $m$ ) Have you felt so absorbed in your work to-day that you have not noticed a need for company?

(n) Have you been above or below average in your persistence and perseverance to-day?

(o) Do you feel that your emotional moods have been under very good control or not?

(p) Have you been rather easily startled and distracted by sudden sounds to-day? (q) Did you fall asleep easily last night, or did you suffer from some degree of insomnia?

( $r$ ) Have you spent much time to-day in serious discussions, or intellectual analysis, or not?

The daily behaviour of the subject was also rated on a graphic scale, ranging from 0 to 100 , on thirteen observer evaluations of the same behaviour as is described in the self ratings listed above. This evaluation was done by two acquaintances, one of them being the experimenter who gave the tests each day.*

Since the correlation coefficients between the ratings from the two acquaintances were positive and large, the rating scores were combined. Those between some of the ratings of corresponding behaviour by the observers and by the subject were also large enough to warrant combination in a single score. After the scores were thus combined in trios there were nineteen psychological behaviour scores. $\dagger$

\section{(3) Statistical Analysis of Data}

Before describing the factor analysis, one must attend to the statistical properties of the individual measures. Normality of distribution is not essential to correlation, but it is important to know how large the range of scores is and of what magnitude the experimental error of measurement may be. These are of interest for comparison with other physiological experiments, apart from the present statistical analysis. The ranges are set out in Table $I$ and a sample of the reliability coefficients in Table II.

\section{TABLE II}

\begin{tabular}{l|l}
\multicolumn{1}{c|}{ Test } & Reliability Coefficient \\
\hline Dark-adaptation & 0.84 \\
Blood Pressure & 0.71 \\
$p$ H of Saliva & 0.93 \\
$p$ H of Urine & 0.93 \\
Reaction Time to Light & 0.76 \\
Red Blood Cells & 0.81 \\
\hline
\end{tabular}

The magnitude of experimental error of measurement is properly ascertained by that reliability index which we call the consistency (split-half) coefficient for the coefficient of stability (test-retest) indicates both the inconstancy due to error and that due to function fluctuation. Some physiological research has overlooked this, ascribing the difference between repeat measures of the same thing to error of measurement; but it is actually this true function fluctuation upon which P-technique depends for its discovery of functional unities. Unfortunately the determination of a split-half (consistency) coefficient is not practicable with

* The list of the thirteen items can be found in Williams $(1949,1953)$.

$t$ The correlation coefficients for the ratings made by the two acquaintances, and those for the ratings made by the acquaintances and the subject can be found in Williams (1949. 
many of our measures and we have had to confine ourselves in Table II to those in which an immediate retest of the function could be made on each of the occasions of administration. By the usual standards of reliability of psychological and physiological measurement the values in Table II are good, except for the blood pressure measure, which indicates a moderate experimental error.

All 52 of the physiological and psychological performance measures were intercorrelated in all possible pairs, yielding a total of 1,326 correlations in the correlation matrix.* The three pure behaviour rating variables were not correlated in with this matrix, but their associations were found later by correlating them with the emerging factors.

Naturally, the reader must be referred elsewhere (Cattell, 1952; Thurstone, 1947) for the mathematical presentation of the factor analytic process, but it may be pointed out here that in its simplest form it consists in looking for a number of collections of variables, in each of which all correlations are positive and substantial. That is to say, we look for clusters of variables which "go together" in their day-to-day changes. It is then argued that these variables must be expressive of some single underlying influence, and the nature of the variables gives a hypothesis as to what this influence might be.

In this case, thirteen factors were found necessary to account for the correlations among the 36 physiological variables. No significant residual remained after these thirteen factors were extracted by the multi-group method. As usual, the factors were "rotated" after extraction to find a simple structure, i.e. a position of maximum meaning (Cattell, 1952; Thurstone, 1947). After eleven over-all blind rotations, i.e. without guidance by physiological pre-conceptions, a definite, unique simple structure was found, in which, as usual, some slight correlations were found to exist among the distinct factors. It is the factors in this final form of which the following descriptions are given.

A more detailed account of the factor extraction is given in Williams (1949), and the full tables for the correlation matrix, the unrotated factor matrix, the transformation matrix, the inter-factor correlation matrix, and the rotated simple-structure matrix are there presented. Here we present the essence only from the latter matrix, in the form of the highest loaded variables found for each factor. The psychological performance variables have been omitted, for the clearer perception of the purely physiological picture, but are discussed systematically elsewhere (Williams, 1953).

\footnotetext{
*The full Pearsonian formula, $r=\frac{\Sigma(x-\bar{x})(y-\bar{y})}{N \sigma_{x} \sigma \nu}$ was used.
}

It will be understood that we are not trying to explain why or how each of the groupings of variables set out in the following section is to be accounted for by a single factor. For some readers, our interpretation of the various factors may not be adequate, and they may have additional hypotheses as to each of the functional unities presented. Where no explanation suggests itself, we shall simply record the pattern. If, with the increase of factor analytic research, the factor is nevertheless confirmed in a later study, the absence of explanation in terms of current concepts will become a serious challenge, pointing to missing hypotheses in current explanations and in existing knowledge of the functions of the organism.

\section{(4) NATURe OF the Functional Unities}

In Table III the four variables in Factor 1 above the 1 per cent. level of significance of correlation with the factor (Saunders' criterion, Cattell, 1952) are set out. Here, as elsewhere, whenever a loading is negative the verbal description of the variable is inverted also, e.g. a high ketosteroid concentration is written low, for this is the meaning of the negativeness of loading. Incidentally, if we knew the consistency coefficients of all variables, the loadings would be, with advantage, "corrected for attenuation" (Cattell, 1952), which would place them in a slightly different order, but some allowance frong general knowledge of consistency can be made mentally in our interpretations.

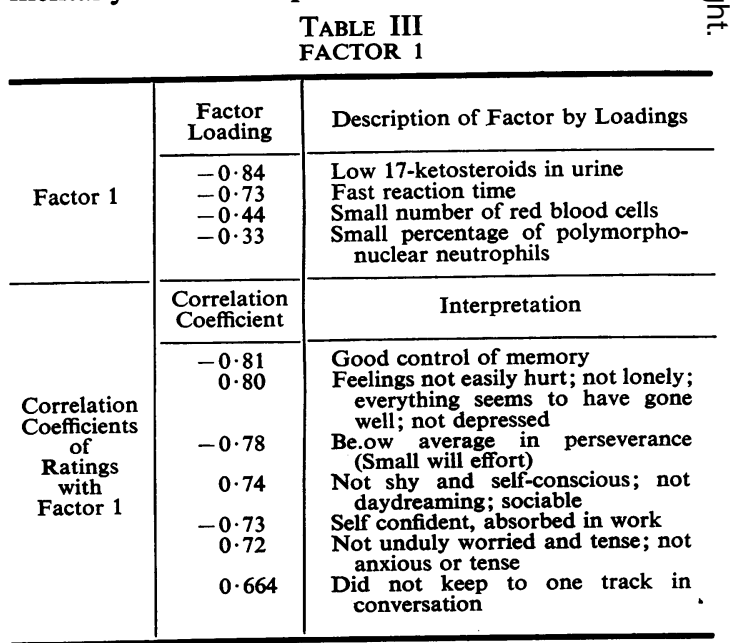

We are probably safe in ruling out a first possibility that Factor 1 is a functional unity present when there is infection, for although Forbes and others (1947) have shown that as little as 30 per cent. of the normal amount of 17-ketosteroids is excreted when there is an acute infection, as in appendicitis, segmented 
cells are very few, and, more conspicuously, white blood cells are not numerous.

The small number of red blood cells would indicate that the subject is in an opposite state from one of emotional strain, for many investigators such as Sanford (1943), and Cattell and Luborsky (1950) have pointed out a pattern of emotional polycythaemia.

The outstanding feature of this factor is its very high correlation with those psychological rating variables which are consistent in indicating confidence, good command of memory, self-sufficiency, and freedom from anxiety.

Our hypothesis will be that this factor corresponds in its positive direction, to a state of being well rested, with large unused physiological reserves, and, in its opposite direction, (with a large ketosteroid excretion, slowed reaction time, anxiety, will effort, poor memory and loss of confidence) to that state of stress exhaustion which, Forbes and others (1947), and Selye (1950), have described. If this is correct, it suggests that certain psychological performance measures (Williams, 1949)-notably of reaction time, fluency, and memory - could be combined with the ketosteroid assay to give a more accurate measure of stress exhaustion.

Factor 2 (Table IV) shows a resemblance to Factor 1 in ketosteroid association and some psychological ratings, though the two are nevertheless independent. This example reminds us that one variable may appear in several factors-up to the point when its variance is wholly accounted for, i.e. when the sum of the squares of the loadings equals one. This is likewise generally understood in

TABLE IV

FACTOR 2

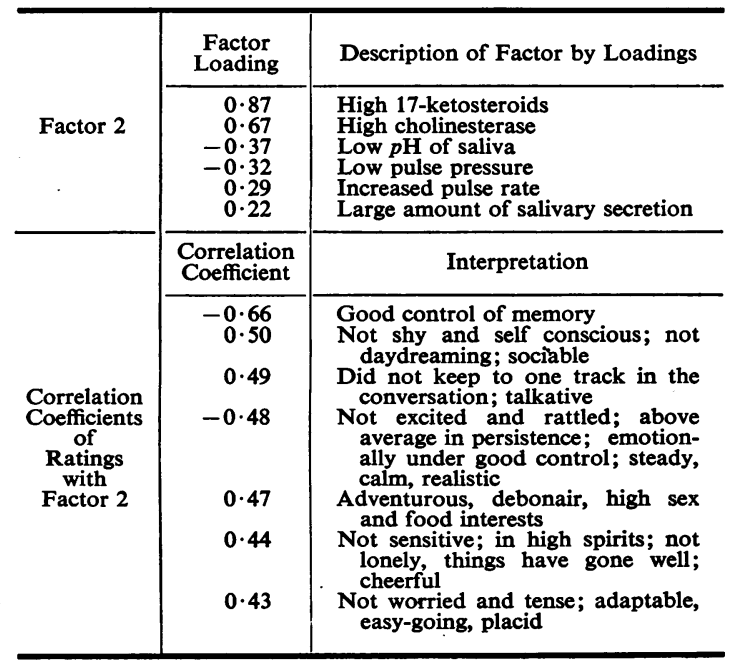

physiological as in statistical terms. For example, we know that a large number of red blood cells might indicate an emotional state, a condition of muscular exercise, haemorrhage, carbon monoxide poisoning, change of climate, a particular diet, etc. In interpreting the presence of a single variable, therefore, we must take the causal explanation indicated by the background of the other variables also found to load the factor under consideration.

As pointed out in Factor 1, Forbes and others (1947) noted that the excretion of 17-ketosteroids is increased when the organism is responding to an emergency such as burns and non-infective surgery. But physiological emergency does not seem to be indicated in Factor 2 in the same way as Factor 1 because of the absence of several physiological variables which one would expect to be present if this were true. Tod and Jones (1937) and Richter and Lee (1942) have shown that patients with anxiety states, or normal subjects subjected to severe worry, show a significant increase in serum cholinesterase. The subject was not rated as anxious or worried in this factor, although in another (Factor 5) it is shown that the serum cholinesterase does increase with worry and anxiety.

If this factor is to be regarded physiologically as a stress influence-and the ketosteroid, cholineesterase, and acid saliva would indicate this-it may be different from the other two stress factors (Factor 1 above and Factor 5) in arising from a high degree of willed, effortful activity imposed by a conscientious, persistent "mood" in the subject.

Factor 3 (Table V) shows the general adaptation syndrome described clinically by Selye (1950), and experimentally by Izquierdo and Cannon (1928). The variables are those which rise together in the countershock phase, with the exception of low diuresis, which belongs to the shock phase but would be TABLE $\mathrm{V}$

\begin{tabular}{|c|c|c|}
\hline \multirow[b]{2}{*}{ Factor 3} & $\begin{array}{l}\text { Factor } \\
\text { Loading }\end{array}$ & Description of Factor by Loadings \\
\hline & $\begin{array}{r}-0 \cdot 71 \\
0 \cdot 55 \\
0 \cdot 52 \\
-0 \cdot 39 \\
-0 \cdot 37 \\
0 \cdot 31 \\
0 \cdot 31 \\
-0 \cdot 31 \\
0 \cdot 27\end{array}$ & $\begin{array}{l}\text { Low calcium content of blood } \\
\text { High blood pressure } \\
\text { Lateness of the session in series } \\
\text { Small percentage of lymphocytes } \\
\text { Low pulse pressure } \\
\text { High glucose content of blood } \\
\text { Large percentage of eosinophils } \\
\text { Small volume of urine } \\
\text { High pulse rate }\end{array}$ \\
\hline \multirow[b]{2}{*}{$\begin{array}{c}\text { Correlation } \\
\text { Coefficients } \\
\text { of } \\
\text { Ratings } \\
\text { with } \\
\text { Factor } 3\end{array}$} & $\begin{array}{l}\text { Correlation } \\
\text { Coefficient }\end{array}$ & Interpretation \\
\hline & $-0 \cdot 200$ & $\begin{array}{l}\text { Not self assertive, lacking in } \\
\text { confidence; not conceited }\end{array}$ \\
\hline
\end{tabular}


recorded here naturally with a time lag. These variables are the raised blood pressure, raised glucose and high pulse rate.

The somewhat puzzling item for such interpretation is the low calcium level. In psychosomatic research apparently contradictory findings exist on calcium level. Glaser (1924), Kretschmer and Kruger (Dunbar, 1946), and Tomasson (1924) find high calcium level with "nervous" individuals; but Cattell and Luborsky (1950) find high calcium level in a behaviour factor of relaxation and low reactiveness. It can be objected to the earlier studies that the definition of the psychological variable "nervous" has varied from timidity, through anxiety and neuroticism, to manic irascibility. In the present study two factors are significantly correlated with calcium level, this and Factor 7, and both have the quality of reaction to some stress.

This factor has some slight relation to psychological ratings of "lacking self-confidence". It fits better the high reactivity of the Cattell and Luborsky factor and the notion of general adaptation syndrome. Incidentally high blood pressure is also found here in three factors and the associations previously found thereto by Herrington (1942) we believe belong to another factor. A low urine volume was found by Mohr (1925) to occur with freedom from anxiety states and that also belongs in another factor from the present one. The low lymphocyte count may be most simply interpreted as freedom from some intermittent infection. In that case the stress situation responsible for this pattern is probably indicated by the correlation with "lateness of session" to be the subject's impatience and annoyance with the prolongation of the test sessions.

Factor 4 (Table VI) is the only factor significantly loaded by the time of day. Since the number of cigarettes smoked, number of urinations, and number of defaecations were scored at the time the tests were given, we would expect their number to increase the later in the day the tests were given. The increase in the number of white blood cells also supports this interpretation, for we know that the

TABLE VI

FACTOR 4

\begin{tabular}{|c|c|c|}
\hline & $\begin{array}{l}\text { Factor } \\
\text { Loading }\end{array}$ & Description of Factor by Loadings \\
\hline Factor 4 & $\begin{array}{r}0.73 \\
0.68 \\
0.62 \\
0.44 \\
0.41 \\
0.32 \\
0.31 \\
-0.30\end{array}$ & $\begin{array}{l}\text { Many hours after waking } \\
\text { Large number of cigarettes smoked } \\
\text { Large number of urinations } \\
\text { Large percentage of eosinophils } \\
\text { Large number of defaecations } \\
\text { Large number of white blood cells } \\
\text { Large ratio of pupil to iris } \\
\text { Small percentage of segmented } \\
\text { nuclear cells }\end{array}$ \\
\hline
\end{tabular}

*This factor has its signs reversed relative to the original matrix Williams (1949) because it is then easier to interpret. minimum number of white blood cells occurs in the morning while the maximum number occurs in the evening. This factor shows no correlation with the ratings, except a slight one with the one question rated by the subject on the amount of time spent in serious discussions (again a matter of time passed). This factor is clearly to be interpreted as diurnal fatigue - that fatigue which is a simple function of the number of hours the subject has been awake. Incidentally, for those not having confidence in factor analysis from experience, the fact that the blind statistical process has here picked out and put together just those variables which increase with hour of day is an example of what is meant by the process yielding functional unities.

There is now reasonably reliable evidence that high serum cholinesterase is associated with states of anxiety, Richter and Lee (1942) and Eysenck's studies on individual differences (Cattell, 1950) show it to be associated with desurgent, i.e. anxiousdepressive, temperaments. However, the problem is one of separating distinct influences on cholineesterase level, for our factorization brings it into three factors, namely Factor 2 (the conscientious effort factor), Factor 5, and Factor 6 below.

The presence in this case of the psychological ratings not present in the others - tense, worried, shy submissive, and paranoid ("fault of others") indicates that Factor 5 (Table VII) represents the desurgent, anxious-depressive pattern previousife found. In agreement with this is the acidity of saliva; previously found with an "overwrought" state (Cattell and others, 1947; Cattell and Luborsky, 1950), and the alkalinity of urine found with

\begin{tabular}{|c|c|c|}
\hline \multicolumn{3}{|c|}{$\begin{array}{l}\text { TABLE VII } \\
\text { FACTOR } 5\end{array}$} \\
\hline & $\begin{array}{l}\text { Factor } \\
\text { Loading }\end{array}$ & Description of Factor by Loadings \\
\hline Factor 5 & $\begin{array}{r}0 \cdot 78 \\
-0 \cdot 71 \\
-0 \cdot 59 \\
-0 \cdot 42 \\
0 \cdot 32 \\
0 \cdot 30\end{array}$ & $\begin{array}{l}\text { High cholinesterase } \\
\text { Low pulse pressure } \\
\text { Low predicted basal metabolism } \\
\text { rate (Gale's formula) } \\
\text { Low } p H \text { of saliva* } \\
\text { High } p H \text { of urine } \\
\text { Large percentage of stab nuclears }\end{array}$ \\
\hline \multirow[b]{2}{*}{$\begin{array}{l}\text { Correlation } \\
\text { Coefficients } \\
\text { of } \\
\text { Ratings } \\
\text { with } \\
\text { Factor } 5\end{array}$} & $\begin{array}{l}\text { Correlation } \\
\text { Coefficient }\end{array}$ & Interpretation \\
\hline & $\begin{array}{r}-0 \cdot 30 \\
-0 \cdot 25 \\
-0 \cdot 23 \\
0 \cdot 21\end{array}$ & $\begin{array}{l}\text { Shy and self-conscious; daydreaming } \\
\text { Submissive, gentle (not confident, } \\
\text { not self assertive, not conceited) } \\
\text { Tense, worried; anxious } \\
\text { It is the fault of others when things } \\
\text { have gone wrong }\end{array}$ \\
\hline
\end{tabular}

* The authors are not attempting in the interpretation of any of the factors to mention all previous research results or to give all possible explanations. For example, the high $\mathrm{pH}$ of the urine and low $\mathrm{pH}$ of the saliva could be the result of the ingestion of $\mathrm{NaHCO}_{3}$ which increases the $\mathrm{CO}_{2}$ tension in the blood. That theory would not explain the presence of high cholinesterase and low basal metabolism rate (predicted) in this factor. Theories are presented only to throw light on the meaning of the entire factor. 
emotional states (Rich, 1928). The whole pattern therefore appears to be that found with the desurgent state of anxiety, depression, agitation, and discouragement.

This pattern in Factor 6 (Table VIII) resembles that recognized through various researches (Cattell, 1950; Cattell and Luborsky, 1950) as one of parasympathetic activity, the markers thereof being the high electrical skin resistance, large PGR response (Freeman and Katzoff, 1942), frequency of urination, and low cholinesterase (Cattell 1950). Darrow and Heath (1932) noted that their subjects with high initial skin resistance show a freedom from depressive and paranoid trends. The only psychological correlation here, though very slight, is also in the direction of freedom from paranoid attitudes. However, the massive loadings here are primarily in physiological variables and indicate a parasympathetic pattern, with indications that future research should extend to considering short recovery of above-threshold visibility after glare, low cholineesterase, and low glucose concentration as integral parts of the pattern.

\begin{tabular}{|c|c|c|}
\hline & & $\begin{array}{l}\text { BLE VIII } \\
\text { ACTOR } 6\end{array}$ \\
\hline \multirow{4}{*}{ Factor 6} & $\begin{array}{c}\text { Factor } \\
\text { Loading }\end{array}$ & Description of Factor by Loadings \\
\hline & $\begin{array}{l}-0.60 \\
-0.53\end{array}$ & \multirow{3}{*}{$\begin{array}{l}\text { Low cholinesterase } \\
\text { Short recovery of above-threshold } \\
\text { visibility after glare } \\
\text { Large volume of urine } \\
\text { Large magnitude of deflections of } \\
\text { PGR } \\
\text { High ability to relax (PGR) } \\
\text { Low glucose content of the blood } \\
\text { High initial PGR resistance } \\
\text { Low pulse rate }\end{array}$} \\
\hline & $\begin{array}{l}0.46 \\
0.44\end{array}$ & \\
\hline & $\begin{array}{r}0.43 \\
-0.44 \\
0.39 \\
-0.29\end{array}$ & \\
\hline \multirow{2}{*}{$\begin{array}{c}\text { Correlation } \\
\text { Coefficients } \\
\text { of } \\
\text { Ratings } \\
\text { with. } \\
\text { Factor } 6\end{array}$} & $\begin{array}{l}\text { Correlation } \\
\text { Coefficient }\end{array}$ & Interpretation \\
\hline & -0.156 & $\begin{array}{l}\text { When things have gone wrong, it } \\
\text { has been mostly my own fault }\end{array}$ \\
\hline
\end{tabular}

The interpretation of Factor 7 (Table IX) is puzzling. The ratings rule out conscious emotionality, such as the glucose figure suggests. A high calcium content of the blood has been found to be concomitant with an increase in the manic state of the individual (Tomasson, 1942), although Cattell and Luborsky (1950) have shown it is sometimes concomitant with relaxation and low reactiveness, which is more in keeping with the present finding. Conceivably the high calcium is associated with a low psychological sensitivity and case of dissociation. Normally this would lead to relaxation, but in states of environmental press it would also lead to insensitive uninhibited manic behaviour. The high self-rating on stuttering, which the subject has often stated he believed to be brought on by tenseness, is not correlated with ratings of tension and anxiety and fits in better with a dissociation theory of stuttering. Perhaps the high glucose content of the blood, high calcium content of the blood, and the large number of lymphocytes indicates that the organism is "pressed" (in Cannon's physiological sense).

\begin{tabular}{|c|c|c|}
\hline \multicolumn{3}{|c|}{$\begin{array}{l}\text { TABLE IX } \\
\text { FACTOR } 7\end{array}$} \\
\hline & $\begin{array}{c}\text { Factor } \\
\text { Loading }\end{array}$ & Description of Factor by Loadings \\
\hline Factor 7 & $\begin{array}{r}0.61 \\
-0.60 \\
0.52 \\
0.51 \\
0.44\end{array}$ & $\begin{array}{l}\text { High glucose content of the blood } \\
\text { Low percentage of polymorpho- } \\
\text { nuclear neutrophils } \\
\text { High calcium content of the blood } \\
\text { High self-rating on stuttering } \\
\text { Large percentage of lymphocytes }\end{array}$ \\
\hline & $\begin{array}{c}\text { Correlation } \\
\text { Coefficient }\end{array}$ & Interpretation \\
\hline $\begin{array}{l}\text { Correlation } \\
\text { Coefficients } \\
\text { of } \\
\text { Ratings } \\
\text { with } \\
\text { Factor } 7\end{array}$ & $\begin{array}{r}0.30 \\
-0.29 \\
-0.27 \\
0.25 \\
-0.25 \\
-0.22 \\
0.21\end{array}$ & $\begin{array}{l}\text { Not shy and self-conscious; not } \\
\text { day-dreaming; sociable } \\
\text { When things have gone wrong } \\
\text { today, it has been mainly my own } \\
\text { fault } \\
\text { Self-confident; absorbed in work } \\
\text { Not sensitive; in high spirits; not } \\
\text { lonely; things have gone well; } \\
\text { cheerful } \\
\text { Memory under good control } \\
\text { Not excited; persevering; emotional } \\
\text { moods under control; calm, } \\
\text { steady sty } \\
\text { Not startled and distracted by } \\
\text { sudden sounds }\end{array}$ \\
\hline
\end{tabular}

Factor 8 (Table $\mathrm{X}$ ) resembles one found by Uhlenbruck and Gildemeister (Woodworth, 1938) which they entitled "autonomic reflex". They found a factor which showed a concomitance of PGR deflections and dilation of the pupil. The percentage deflections of PGR, which indicates momentary spurts of activity by means of the sympathetic nervous system, have a relatively low but positive loading in this factor. Factor. 8 is also similar to results found by Freeman and Katzoff (1942) and Darrow and Heath (1932) which are indicative of "autonomic activity".

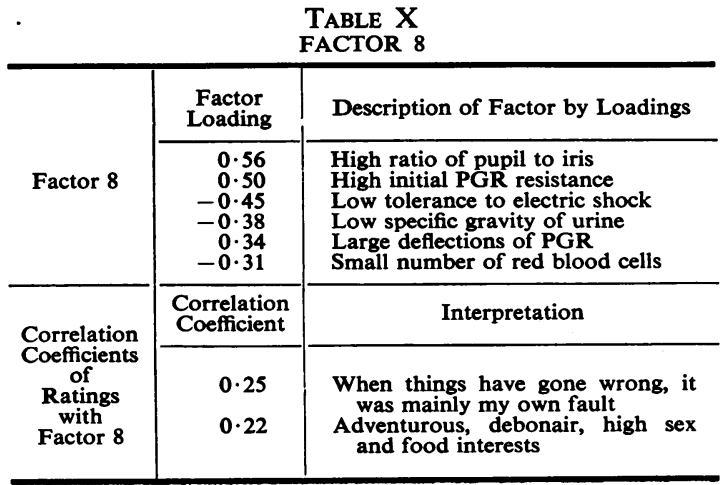


In Factor 9 (Table XI) the "later sessions" correlation might suggest that the later tests were taken after a meal, which might fit the acidity of the saliva and some of the psychological ratings of relaxation. There are resemblances to the pattern of a factor (Cattell, 1946, 1950; Cattell and other, 1947) of easygoing, adaptable cyclothyme behaviour. Contingently, we must leave it either as a pattern of relaxed temperament or as one of relaxation after a meal.

\begin{tabular}{|c|c|c|}
\hline \multicolumn{3}{|c|}{$\begin{array}{r}\text { TABLE XI } \\
\text { FACTOR } 9\end{array}$} \\
\hline & $\begin{array}{l}\text { Factor } \\
\text { Loading }\end{array}$ & Description of Factor by Loadings \\
\hline Factor 9 & $\begin{array}{r}-0 \cdot 80 \\
-0 \cdot 56 \\
-0 \cdot 36 \\
0 \cdot 34 \\
0 \cdot 34\end{array}$ & $\begin{array}{l}\text { Low pH of saliva } \\
\text { Short recovery of above-threshold } \\
\text { visibility after glare } \\
\text { Low pulse pressure } \\
\text { Lateness of session in the series } \\
\text { High PGR initial resistance }\end{array}$ \\
\hline & $\begin{array}{l}\text { Correlation } \\
\text { Coefficient }\end{array}$ & Interpretation \\
\hline $\begin{array}{l}\text { Correlation } \\
\text { Coefficients } \\
\text { of } \\
\text { Ratings } \\
\text { with } \\
\text { Factor } 9\end{array}$ & $\begin{array}{r}0 \cdot 37 \\
-0.33 \\
0.32 \\
0.31 \\
0.26 \\
-0 \cdot 26 \\
0.24\end{array}$ & $\begin{array}{l}\text { Persevering, conscientious } \\
\text { Not excited; above average in } \\
\text { persistence; emotional moods } \\
\text { under good control; steady, calm } \\
\text { Have not kept to one track in the } \\
\text { conversation; talkative } \\
\text { Not sensitive; in high spirits; not } \\
\text { lonely; things have not gone } \\
\text { wrong today; cheerful } \\
\text { Not worried and tense; adaptable, } \\
\text { easy going, placid } \\
\text { Memory under good control } \\
\text { Accommodating, communicative, } \\
\text { dependent }\end{array}$ \\
\hline
\end{tabular}

In Factor 10 (Table XII) the highest variable is one associated with sympathetic nervous system reactivity and the others are in keeping (Darling, 1940). But since Factor 3 has been thought to represent the general adaptation syndrome (Selye, 1950), we are forced to hypothesize that a limited sympathetic nervous system reaction pattern exists additional to the total syndrome of the general adaptation response. Indeed when contrasted with the sympathetic-adrenergic pattern as set out elsewhere (Cattell, 1950) this lacks the low skin resistance and high pulse pressure.

TABLE XII

FACTOR 10

\begin{tabular}{|c|c|c|}
\hline & $\begin{array}{l}\text { Factor } \\
\text { Loading }\end{array}$ & Description of Factor by Loadings \\
\hline Factor 10 & $\begin{array}{r}0 \cdot 31 \\
-0 \cdot 30 \\
0 \cdot 30\end{array}$ & $\begin{array}{l}\text { High ratio of pupil to iris } \\
\text { Small volume of urine } \\
\text { High glucose content of blood } \\
\text { serum }\end{array}$ \\
\hline
\end{tabular}

In a previous study (Cattell and others, 1947) high frequency of PGR responses when unstimulated has been definitely found associated with a fatigue factor. The substantial correlation $(0.42)$ with lack of sleep found in Factor 11 (Table XIII) fits this interpretation, as also does the tolerance of high electric shock.
The subject is jaded, and this is perhaps indicated also by the lateness of session correlation, for the subject became increasingly bored, though the observers' ratings are of "shyness" and lacking confidence. The substantial correlation with red blood cell count and with volume of urine seems to indicate some continued sympathetic system response (Selye's "resistance phase"?) but cannot at this point be more precisely interpreted.

\begin{tabular}{|c|c|c|}
\hline \multirow[b]{2}{*}{ Factor 11} & $\begin{array}{c}\text { Factor } \\
\text { Loading }\end{array}$ & Description of Factor by Loadings \\
\hline & $\begin{array}{l}0 \cdot 63 \\
0 \cdot 53 \\
0 \cdot 52 \\
0 \cdot 40 \\
0 \cdot 30\end{array}$ & $\begin{array}{l}\text { Great endurance of electric shock } \\
\text { Large number of red blood cells } \\
\text { Large volume of urine } \\
\text { Great frequency of PGR deflections } \\
\text { Lateness in the session series }\end{array}$ \\
\hline \multirow[b]{2}{*}{$\begin{array}{l}\text { Correlation } \\
\text { Coefficients } \\
\text { of } \\
\text { Ratings } \\
\text { with } \\
\text { Factor } 11\end{array}$} & $\begin{array}{l}\text { Correlation } \\
\text { Coefficient }\end{array}$ & Interpretation \\
\hline & $\begin{array}{r}0.42 \\
0 \cdot 26 \\
0 \cdot 25 \\
-0 \cdot 22\end{array}$ & $\begin{array}{l}\text { Suffered from some degree of } \\
\text { insomnia } \\
\text { when things have gone wrong, it } \\
\text { has been the fault of others } \\
\text { Lacking in self-confidence; not } \\
\text { absorbed in work } \\
\text { Daydreaming; shy and self-con- } \\
\text { scious; self-contained, withdrawn }\end{array}$ \\
\hline
\end{tabular}

- Using Wilson's index of resistance, the low number of polymorphonuclear neutrophilic leucocytes in Factor 12 (Table XIV, opposite) indicates a low physi cal resistance to infection.* The large number of stab nuclears indicates a shift to the left of the Arnetk index. We know this occurs along with a high tota white blood cell count in cases of appendicitis, acute sepsis, etc. The shift to the left in the Arneth index, occurring along with a diminished total white blood cell count is neither low nor high. Perhaps the large percentage of stab nuclears indicates a lowered resistance, although no specific disease was present. This is the only factor which has even a slight correlation with longer sleep (recorded) the previous night.

In Factor 13 (Table XV, opposite) the cigarettes smoked, having no relationship to the number of hours after awakening, may signify a tension or a substitution of smoking for eating, sometimes noted with this subject. Since volume of urine is not one of the items loading this factor, the low specific gravity of urine may fit in with this. The small number of eosinophils would indicate that there is no

* Wilson's formula is as follows: $I R=(T-10)(P-20)$; IR being the "index of resistance", $T$ the total leucocyte count expressed in thousands, and $\mathbf{P}$ the polymorpho-neutrophilic percentage. Since the total number of white blood cells is neither large nor small in this factor, we shall assume it is average, i.e. 5,000 per cu. mm. Since the average neutrophilic percentage of white blood cells is 60 or 70 per cent. and since it is lower than average in this factor, let us assume the percentage to be 50 . Our formula would then be as follows: IR = $(5-10)-(50-20)$ which would give a minus quantity. According to Wilson, a minus quantity indicates a low power of resistance. 


\begin{tabular}{|c|c|c|}
\hline \multicolumn{3}{|c|}{$\begin{array}{ll}\text { TABLE XIV } \\
\text { FACTOR } 12\end{array}$} \\
\hline & $\begin{array}{l}\text { Factor } \\
\text { Loading }\end{array}$ & Description of Factor by Loadings \\
\hline Factor 12 & $\begin{array}{r}0 \cdot 81 \\
-0 \cdot 40 \\
0 \cdot 37 \\
-0 \cdot 34 \\
-0.33 \\
0 \cdot 17\end{array}$ & $\begin{array}{l}\text { High specific gravity of urine } \\
\text { Small percentage of polymorpho- } \\
\text { nuclear neutrophils } \\
\text { Large percentage of stab nuclears } \\
\text { Small percentage of basophils } \\
\text { Small number of eosinophils } \\
\text { More sleep than usual previous } \\
\text { night }\end{array}$ \\
\hline \multirow[b]{2}{*}{$\begin{array}{l}\text { Correlation } \\
\text { Coefficients } \\
\text { of } \\
\text { Ratings } \\
\text { with } \\
\text { Factor } 12\end{array}$} & $\begin{array}{l}\text { Correlation } \\
\text { Coefficient }\end{array}$ & Interpretation \\
\hline & $\begin{array}{r}0 \cdot 34 \\
-0.32 \\
\\
0 \cdot 30 \\
\\
0 \cdot 29 \\
0 \cdot 28 \\
0.27 \\
0.26\end{array}$ & $\begin{array}{l}\text { Accommodating, communicative, } \\
\text { dependent } \\
\text { Not excited, above average in } \\
\text { presistence; emotional moods } \\
\text { under control; steady, calm, } \\
\text { realistic } \\
\text { Not sensitive; in good spirits; not } \\
\text { lonely; things have gone well; } \\
\text { cheerful } \\
\text { Persevering, conscientious } \\
\text { Not worried and tense; adaptable, } \\
\text { easy going, placid, } \\
\text { Vigorous, co-operative } \\
\text { Mind has not kept to one track in } \\
\text { conversation; talkative }\end{array}$ \\
\hline
\end{tabular}

\begin{tabular}{|c|c|c|}
\hline \multicolumn{3}{|c|}{$\begin{array}{l}\text { TABLE XV } \\
\text { FACTOR } 13\end{array}$} \\
\hline & $\begin{array}{l}\text { Factor } \\
\text { Loading }\end{array}$ & Description of Factor by Loadings \\
\hline Factor 13 & $\begin{array}{r}0.56 \\
-0.52 \\
-0.43 \\
-0.35\end{array}$ & $\begin{array}{l}\text { Large number of cigarettes smoked } \\
\text { Low specific gravity of urine } \\
\text { Small percentage of eosinophils } \\
\text { Low basal metabolism rate (pre- } \\
\text { dicted from Gale's formula) }\end{array}$ \\
\hline Correlation & $\begin{array}{l}\text { Correlation } \\
\text { Coefficient }\end{array}$ & Interpretation \\
\hline $\begin{array}{l}\text { of } \\
\text { Ratings } \\
\text { with } \\
\text { Factor } 13\end{array}$ & $-0 \cdot 22$ & Stern, solemn, secretive \\
\hline
\end{tabular}

presence of an allergy or asthma. The low predicted basal metabolism rate indicates a phlegmatic or apathetic state since pulse rate and basal metabolism rate has been shown to be positively related to physical energy (Glaser, 1924). The physiological variables, along with the rating "stern, solemn, secretive", point to some apathy or withdrawal, As usual in factor analytic work, the last two or three factors are the hardest to interpret and should have their uncertain patterns confirmed by repeat studies before more extensive discussion is attempted.

\section{(5) General Discussion}

Of the thirteen factors discovered, perhaps a half have sufficient resemblance to known syndromes, previously located factors, or the expected results of processes recognized by present physiological knowledge to "make sense". The remainder can be considered as a challenge to physiological hypothesis formation-a serious challenge if confirmed by another P-technique study-or as a reflection on the soundness of the method. Let us examine the latter possibility and ask in what ways it could be improved.

In the first place, it is likely that research physiologists will be able to suggest from up-to-date hunches certain theoretically important variables, repeatable from day to day, not included in those suggested by our initial survey of the field. Such should certainly be included with the present battery in a follow-up. Secondly, with our psychological prepossessions, we have probably been too optimistic about the fraction of the variance contributed by emotional conditions relative to that arising from physical conditions, and have consequently failed to include sufficient variables defining the latter (it is, with this design, not a question of "holding the latter constant"). Chiefly we are aware, in retrospect and in view of the speculation caused by certain patterns, that we did not include enough information about the subject's food intake and the time relations of the sessions to meal times. Perhaps there should have been closer records also of intercurrent "colds" or other infections.

Apart from the nature of the variables and conditions of their measurement, which can be readily adjusted to further suggestions, there is also a systematic defect in the new method-or, at least, a difficulty in aligning the concepts which emerge from it with those familiar to the physiologist from the classical "controlled experiment" method. In the latter it is easy, and usual, to distinguish, by means of the known time sequence, between causes and effects, i.e. independent and dependent variables. In factor analysis all that we have is proof of association (correlation with the same factor) and no indication of which variable is prior. An argument can be made, it is true, for the conclusions that the factor itself (some entity behind the correlated variables) is the cause, and that the correlated variables are in the chain of consequences, but this is a complex matter (Cattell, 1952). Without resort to such a solution, we can nevertheless take up the methodological position that factor analysis has its important role as an exploratory device in a poorly structured, chaotic area, and that its aim is to reveal collections of associated variables which immediately suggest hypotheses that can thereafter be investigated more closely by the methods of controlled experiment.

In comparing the results of the present correlation method with those of experiments which use comparison of means or analysis of variance, it must be constantly borne in mind that, whereas the latter is 
unaware of what happens to the variance (other than that with which it is directly concerned), the factor analytic specification equation allocates the total variance in a variable to all the factor influences involved. The fact that variable $x$ enters into the pattern of Factor $A$ and has part of its variance determined thereby, does not prevent its also having part of its variance determined by Factors B, C, etc. This is frequently overlooked in isolated experiments with few variables which lead to "explanations" of the source of variance in some physiological variables which are necessarily conflicting. Experimental concentration on one role of a variable then often causes its other roles and pattern associations to be overlooked. The total factor analytic approach, with the specification equation (which we have not employed here, as being unnecessarily technical), thus enables one to perceive from the beginning that only a certain fraction of the variable's variance can be attributed to a given cause, whereas the experimental study of two variables at a time would leave one quite in the dark as to where the unaccounted causality lies.

\section{(6) Summary}

The correlation of 36 physiological variables and nineteen psychological variables measured on a normal 23-year-old male for 110 successive days has yielded clusters of significant correlation coefficients which indicate that a considerable fraction of the day-to-day variation of measurement is due to fluctuation of unitary underlying functions rather than experimental error of measurement.

Application of factor analysis to the correlations by the method of P-technique shows that the variations can be accounted for by thirteen independent influences. From the nature of the variables highly involved (correlated) with these factors it is possible to make preliminary hypotheses about the nature of each, as follows:

(1) A factor of "Large Physiological Reserves (well rested)"- $v s$ - "Exhaustion or Inhibited" marked by large ketosteroid excretion, slowed reaction time, low fluency, anxiety, and lack of confidence.

(2) A factor of "Sustained conscientious effort"- $v s-$ "Laxness", the first pole having some fatigue elements as in Factor I above, but otherwise different, by inclusion of high cholinesterase, acid trend in saliva, low pulse pressure, and positive psychological performances.

(3) A factor having the patterns of what has been described clinically as the "general adaptation syndrome" (Selye, 1950), and more precisely as counter-Shock reaction. The correlations show raised blood pressure, blood glucose, and pulse rate, and inhibition of diuresis.
'The factor pattern is also marked by significantly lower blood calcium and by a rise in general psychological reactivity.

(4) A regular diurnal variation, or hour-of-day factor, associated principally with increase of white blood cell count.

(5) A factor which extends farther into physiological manifestations the factor of "surgency"- $v s$ - "desurgency", already established in psychological variables. This shows that the desurgent pole (anxiety, worry, depression, suspicion) is associated with high serum cholinesterase, acidity of saliva, alkalinity of urine, low pulse pressure, and low predicted basal metabolism rate.

(6) A second pattern with one or two of the elements in five, but considered to be the parasympathetic syndrome showing high electrical skin resistance, low blood sugar, large PGR deflection, much diuresis, low cholinesterase, and short recovery of above-threshold visibility after glare.

(7) A factor, independent of that of the general adaptation syndrome, yet resembling it and considered to be a sympathetic nervous system reactivity, showing high blood sugar, reduction of urine volume, and large ratio of pupil to the iris.

(8) A sleeplessness factor, marked principally by inê స్ creased red blood cell count and frequency of spontaneous psychogalvanic responses.

Five further factors were found, one connected with high calcium content of the blood, but these are too new to justify hypotheses until confirmed in a second study.

In general, these results show that factor analysis is capable of structuring a wide array of physiological manifestations in a way not possible by any other method. Controlled experiments, however, are desirable if these findings by the exploratory, factor-analytic method are to be followed up to give causal explanation of the associations. They also show substantial relations between the physiological patterns and some of the factor patterns previously recognized in psychological (total behaviour) variables. It is to be hoped that physiologists specializing in particular fields may be able to suggest more detailed explanations for some of these observed correlations.

The authors wish to express their gratitude to the subject for so willingly aiding in this project, to Burnham City Hospital, Champaign, Ill., for making daily measurements of the glucose and calcium content of the blood serum, to Dr. Melampy and Mr. W. A. Teppert, both formerly of the Physiology Department of the University 
of Illinois, for making the determinations of the 17-ketosteroids and cholinesterase, respectively, to Drs. Hudson Hoaglund, W. B. Stone, and Ladd Prosser for suggestions, and to Dr. D. R. Saunders for his generous aid and advice with the IBM work.

\section{REFERENCES}

Alles, G. A., and Hawes, R. C. (1940). J. biol. Chem., 133, 375.

Best, C. H., and Taylor, N. B. (1945). "The Physiological Basis of Medical Practice", 4th ed. Williams and Wilkins, Baltimore.

Cattell, R. B. (1929). Brit. J. Psychol., 19, 357.

(1946). "Description and Measurement of Personality", p. 602.

World Book Co., Yonkers-on-Hudson, New York.

(1950). "Personality". McGraw-Hill, New York.

(1952). "Factor Analysis". Harper, New York.

Catteli, A. K. S., and Rhymer, R. M. (1947). Psychometrika, 12, 267.

and Luborsky, L. B. (1950). J. gen. Psychol., 42, 3.

Cureton, T. K. (1947). "Physical Fitness Appraisal and Guidance". Mosby, St. Louis.

Darling, R. P. (1940). J. abnorm. soc. Psychol., 35, 246.

Darrow, C. W., and Heath, L. L. (1932). In "Studies in the Dynamics of Behaviour", ed. K. S. Lashley. University of Chicago Press, Chicago.

Dunbar, F. (1946). "Emotions and Bodily Changes", 3rd ed., Columbia University Press, New York.

Forbes, A. P., Donaldson, E. C., Reifenstein, E. C., and Albright, F. (1947). J. clin. Endocr., 7, 264.

Freeman, G. L., and Katzoff, E. T. (1942). J. exp. Psychol., $31,527$.

Glaser, F. (1924). Med. Klin., $20,535$.
Herrington, L. P. (1942), In McNemar, Q., and Merrill, M. A. "Studies in Personality", contributed in Honor of Lewis $\mathbf{M}$. Terman. McGraw Hill, New York.

Izquierdo, J. J., and Cannon, W. B. (1928). Amer. J. Physiol., 84, 545.

Mohr, F. (1925). "Psychophysische Behandlungsmethoden". Hirzel,

Lich, G. J. (1928). Arch. Neurol. Psychiat., Chicago, 20, 589.

Rich, G. J. (1928). Arch. Neurol. Psychiat., Chicago, 20,

Sanford, R., N., Adkins, M. M., Milier, R. B., Cobb, E. A., and others (1943). "Physique, personality and scholarship". Monogr. Soc. Res. Child Dev., 8, No. 1. (Serial No. 34.)

Selye, H. (1950). "The Physiology and Pathology of Exposure to Stress". Acta Inc., Montreal. (Usually called simply by covertitle "Stress".)

Stedman, E., Stedman, E., and Easson, L. H. (1932). Biochem. J., 26, 2056

Thurstone, L. L. (1947). “Multiple Factor Analysis". University of Chicago Press, Chicago.

Tod, H., and Jones, M. S. (1937). Quart. J. Med., n.s. 6, 1.

Todd, J. C., and Sanford, A. H. (1939). "Clinical Diagnosis by Laboratory Methods", 9th ed. Saunders, Philadelphia and London.

Tomasson, H. (1924), Klin. Wschr., 3, 2055.

Tomasson, H. (1924). Klin. Wschr., 3, 2055. factors in the psychosomatic areas." Ph.D. Thesis, University of Illinois, Urbana, Illinois.

(1953). "A Determination of psychosomatic functional unities in personality by means of P-technique. J. soc. Psychol. In the

Woodworth, R. S. (1938). "Experimental Psychology". Holt, New York.

Additional References not Specified in Text

Adler, E. (1932. Zbl. Psychotherap., 5, 131.

Bucciardi, G. (1928). Arch. Fisiol., 26, 1. 